\title{
Did the 2017 Tax Reform Discriminate against Blue State Voters?
}

\author{
David Altig, Alan Auerbach, Patrick Higgins, Darryl Koehler, \\ Laurence Kotlikoff, Michael Leiseca, Ellyn Terry, and Victor Ye
}

\author{
Working Paper 2019-7 \\ April 2019
}

\begin{abstract}
The Tax Cut and Jobs Act of 2017 (TCJA) made significant changes to corporate and personal federal income taxation, including limiting the SALT (state and local property, income and sales taxes) deductibility to $\$ 10,000$. States with high SALT tend to vote Democratic. This paper estimates the differential effect of the TCJA on red- and blue-state taxpayers and investigates the importance of the SALT limitation to this differential. We calculate the effect of permanent implementation of the TCJA on households using The Fiscal Analyzer: a life-cycle, consumption-smoothing program incorporating all major federal and state fiscal policies. We find that the average percentage increase in remaining lifetime spending under the TCJA is 1.6 percent in red states versus 1.3 percent in blue states. Among the richest 10 percent of households, this differential is larger. Rich households in red states enjoyed a 2.0 percent increase compared to a 1.2 percent increase among the rich in blue-state households. This gap is driven almost entirely by the limitation on the SALT deduction. Excluding the SALT limitation from the TCJA results in a spending gain of 2.6 percent for rich red-state households compared to 2.7 percent for rich blue-state households.
\end{abstract}

JEL classification: D15, D31, D72, E62, H20, H22, H71

Key words: fiscal policy, elections, Tax Cuts and Jobs Act, resource distribution, federal tax reform, state and local taxes, life cycle model

https://doi.org/10.29338/wp2019-07

The views expressed here are those of the authors and not necessarily those of the Federal Reserve Bank of Atlanta or the Federal Reserve System. Any remaining errors are the authors' responsibility.

Please address questions regarding content to David Altig, Federal Reserve Bank of Atlanta, Dave.Altig@atl.frb.org; Alan Auerbach, University of California at Berkeley, auerbach@econ.berkeley.edu; Patrick Higgins, Federal Reserve Bank of Atlanta, patrick.higgins@atl.frb.org; Darryl Koehler, Economic Security Planning Inc., darryl.koehler@gmail.com; Laurence Kotlikoff, Boston University, kotlikoff@gmail.com; Michael Leiseca, Economic Security Planning Inc., mleiseca@gmail.com; Ellyn Terry, Federal Reserve Bank of Atlanta, ellyn.terry@atl.frb.org; or Victor Ye, Boston University, yifanye82@gmail.com.

Federal Reserve Bank of Atlanta working papers, including revised versions, are available on the Atlanta Fed's website at www.frbatlanta.org. Click "Publications" and then "Working Papers." To receive e-mail notifications about new papers, use frbatlanta.org/forms/subscribe. 


\section{Introduction}

The 2017 Tax Cut and Jobs Act (TCJA) represents the most significant change to U.S. personal and corporate income taxation since the 1986 Tax Reform Act. The TCJA's personal tax changes reduced the top marginal tax rate, eliminated exemptions, expanded the child tax credit, expanded the standard deduction, lowered the cap on future mortgage-interest deductions, and introduced a $\$ 10,000$ limitation on the amount of state and local taxes (SALT) that can be deducted. Previously there was no limit, except for those subject to the Alternative Minimum Tax (AMT). This paper estimates the effect of these changes on U.S. households and demonstrates that the reduction in taxes and corresponding increase in remaining lifetime spending differentially affected residents of particular states, which we classify as blue, red or purple based on their recent voting behavior in presidential elections.

Our analysis is based on a detailed life-cycle consumption-smoothing program called The Fiscal Analyzer, or TFA, described in Kotlikoff (2019). Auerbach, et al.(2016, 2017, and 2018) have used TFA to study overall fiscal progressivity, remaining marginal net lifetime tax rates on working, and the progressivity of the TCJA. This study is the first use of TFA to study how changes in federal taxes differentially impact households who differ not only by resource percentile within age cohort, but also by state.

To explore red-blue TCJA differences, we designate states, including the District of Columbia, as blue, red or purple based on the average voter margin over the past five presidential elections. States where the Republican share of total votes was, on average, five percentage points higher than the Democratic share of total votes over the past five presidential elections are classified as red. States where the Democratic share of total votes was, on average, five percentage points higher than the Republican share of total votes over the past five presidential elections are classified as blue. The remaining states are classified as purple.

To examine the distributional impact of the TCJA, we classify households in the Federal Reserve Board's 2016 Survey of Consumer Finances (SCF) into "resource" percentiles based on how much human wealth (such as wage income) and non-human wealth (such as home equity) they are projected to have over their lifetime relative to their same-aged peers. ${ }^{1}$ Lifetime resources for households, along with lifetime spending and net-taxes (taxes minus transfers), are projected using TFA, which incorporates details of all major federal and state tax and transfer payment policies.

TFA also incorporates pre-TCJA personal and corporate-income tax codes. As an output, TFA imputes and projects all taxes paid over the lifetime, discounting all to present value. ${ }^{2}$ Hence, it can be used to measure the TCJAinduced percentage change in the discounted present value of remaining lifetime spending for each SCF household. To determine differences in annual TCJA treatment by state, each SCF household is run through TFA 51 times (once for each state, and the District of Columbia). In each of these 51 runs through TFA, state-specific fiscal policies are applied and state-specific weights are assigned to each SCF observation.

Throughout our analysis we assume that the provisions of the TCJA are

\footnotetext{
${ }^{1}$ Households are grouped into 6 age buckets: 20-29, 30-39, 40-49, 50-59, 60-69, and 70-79.

${ }^{2}$ Federal and state corporate income taxes are assumed to be 100 percent borne by owners of all assets. Employer-paid FICA taxes are assumed to be 100 percent borne by workers.
} 
made permanent. According to our findings, red-state households enjoy, on average, a 1.6 percent increase in lifetime spending (henceforth, spending) due to permanent implementation of the TCJA. This compares to a 1.3 percent increase in spending for blue-state households. The state with the highest gain - 2.1 percent - is Wyoming - a red state. The state with the smallest gain 0.9 percent - is California- a blue state.

The red-blue differential is explained by the limitation on the SALT deduction. Excluding the SALT limitation from TCJA, the average red-state spending gain is 1.9 percent versus 2.1 percent for blue states. In particular, "rich" households in red states receive less favorable treatment than "rich" households in blue states, where SALT tend to be much higher. For example, red-state households in the top 10 percent of the national age-specific resource distribution receive a 2.0 percent boost to their remaining lifetime spending compared to just 1.2 percent for blue-state top 10-percenters. If changes to SALT had not occurred, the gains in spending would have been very similar for the top 10 percent regardless of state. In our "NO SALT" scenario, the richest 10 percent of households in red states would receive a 2.6 percent increase in spending versus 2.7 percent in blue states. Thus the differential between the top $10 \%$ in red and blue states is driven almost entirely by SALT.

This paper proceeds in section 2 with a brief overview of the TCJA. Section 3 presents our data and methodology for computing the change in lifetime spending. Section 4 presents basic results and then considers the extent to which differences by state are due to socioeconomic factors or state tax policies, including SALT. Section 5 concludes.

\section{The Tax Cuts and Jobs Act of 2017}

The Tax Cuts and Jobs Act of 2017 (TCJA) was the most comprehensive tax reform passed since the Tax Reform Act of 1986. In addition to modifying individual income tax rates, including reducing the top rate from 39.6 percent to 37.0 percent, the TCJA modified amounts and/or limits for a number of important individual tax credits, deductions, exemptions and penalties. In particular, the standard deduction was nearly doubled for both individual and married filers, thresholds for the Alternative Minimum Tax and the estate tax were raised, and a $\$ 10,000$ limit for itemized deductions on state and local taxes was introduced. No Democrat voted for the passage of the TCJA, while only 12 House Republicans voted against passage. All but one of the 12 Republicans that voted "no" represented "blue" states. In many of these cases, the limit on the SALT deduction was cited as a factor in their vote. ${ }^{3}$

This is not the first time SALT deductions have been under fire. The complete elimination of SALT deductions was included in the initial Reagan Administration Treasury Department 1984 tax reform proposal. However, apart from removing deductibility of retail sales taxes ${ }^{4}$, there were no other

\footnotetext{
${ }^{3}$ The Senate passed the TCJA 51 to 48 with no Republicans voting against it and no Democrates voting for it. Of the 12 House Republicans voting against TCJA, five were from New York, four from New Jersey, two from California, and one from the "red" state of North Carolina. For examples of Congressional statements citing the SALT deduction limit as a factor in the "no" votes, see https://zeldin.house.gov/media-center/press-releases/rep-zeldin-votes-nofinal-tax-reform-bill, https://stefanik.house.gov/media-center/press-releases/stefanik-oppose-finaltax-bill, and https://www.silive.com/news/2017/12/rep_donovan_voted_no_on_final.html.

${ }^{4}$ Deductibility was partially restored with the American Jobs Creation Act of 2004 (Sammartino
} 
changes to SALT deductibility in the 1986 Act (Lindsey, 1986).

Prior to the passage of the TCJA, there was evidence to suggest that blue states might be hurt if SALT were to be modified. For example, Sammartino and Rueben (2016) used the Urban-Institute Brookings Tax Policy Center Microsimulation Model (UBTPC model) to show that repealing, modifying or replacing SALT deductibility would have the most adverse effects for average federal tax rates in high-tax states with a relatively large number of highincome households, such as New York and Connecticut (both of which are blue). The least adverse effects were found for low-tax states, such as South Dakota and Wyoming (both of which are red).

Since the passage of the TCJA, several researchers have studied the impact of the law along party lines. Auerbach et al.(2018) concluded that the reforms in the TCJA were, on the whole, neither progressive nor regressive. However, Sammartino et al.(2018) found that among the U.S. states, there were "winners" and "losers". Using the UBTPC model, these authors also found that for 2018 income and tax outcomes, the TCJA was more beneficial for red states than for blue. ${ }^{5}$ In terms of 2018 outcomes, Sammartino et al. also found the TCJA's $\$ 10,000$ SALT limit was much of the reason the low-tax state of Texas benefited more, on average, than the high-tax state of New York.

A limitation of Sammartino et al. (2018) is the use of traditional static tax burden analysis, which compares current taxes with current income. Auerbach et al.(2018) point out the limitation of this approach, arguing that a forwardlooking, lifetime approach is more consistent with economic theory and can produce different answers than static analysis. As in Auerbach et al.(2018), the focus of this study is whether permanent implementation of the TCJA disproportionately impacts red or blue states in terms of the discounted present value of remaining lifetime spending and/or remaining lifetime tax rates. We say permanent because a number of the individual tax provisions in the TCJA are set to expire within 10 years to permit passage with a simple majority of voters in the Senate under the reconciliation process. Following Auerbach et al.(2018), we assume that these expiring provisions will eventually be made permanent. ${ }^{6}$

\section{Methodology and Data}

\subsection{Creating Resource Percentiles}

Throughout this analysis we examine changes in spending at different points in the resource distribution, referring to those in the top 10 percent of resources as the "rich" and those in the bottom 10 percent of resources as the "poor". To create these resource percentiles, we first calculate the amount of resources

and Rueben 2016).

${ }^{5}$ In particular, the authors found that six of the seven states realizing an average after-tax income increase of more than 2.1 percent were red, whereas the three states with increases of less than 1.5 percent were blue. Moreover, the six states, including D.C., where more than 8.0 percent of their tax payers had an increase in their 2018 taxes as a result of the TCJA were all blue and the five states where less than 4.0 percent of their tax payers had increased 2018 taxes were all red.

${ }^{6}$ We don't estimate the effect on pre-tax incomes here. Simulations of the Global Gaidar Model do suggest the TJCA could, over time, raise real before-tax wages by as much as 5.5 percent (see Benzell, Kotlikoff and Lagarda, 2017a and 2017b). We do not consider that scenario here. 
each household is expected to have over their lifetime. $\mathrm{R}$ (hereafter resources), is the sum of private net wealth, $\mathrm{W}$, and human wealth, $\mathrm{H}$. $\mathrm{H}$ is the expected discounted present value of the household's pre-tax remaining lifetime earnings from all sources and $\mathrm{W}$ is the expected discounted present value of the household's assets, such as home equity and savings for retirement.

$$
R=H+W
$$

Details on the calculation of equation (1) are contained in subsection 3.3 below, "The Fiscal Analyzer."

We group households within ten-year age cohorts and then rank each household's resources to create resource percentiles. As in Auerbach et al.(2018), our ten-year age groups reference households whose heads are 20-29, 30-39, 40-49, 50-59, 60-69 and 70-79. Thus, the "rich" consist of the 10 percent highest resource households among heads in their twenties, the top 10 percent of heads in their 30 s, etc.. ${ }^{7}$

We create resource percentiles within age groups for three reasons. First, young households have yet to pay the bulk of their lifetime taxes or receive the bulk of their lifetime transfers. Second, old households have already paid most of their lifetime taxes and have, in many cases, already received a significant share of their lifetime transfers. Third, the life-cycle model predicts what we see in the figure below - remaining lifetime resources ultimately decline with age. This means that lumping together different age groups will treat older people as poorer than younger people even if they have identical lifetime resources measured as of, say age 20 .

Figure 1: Average Lifetime Resources by Age Group and Marital Status

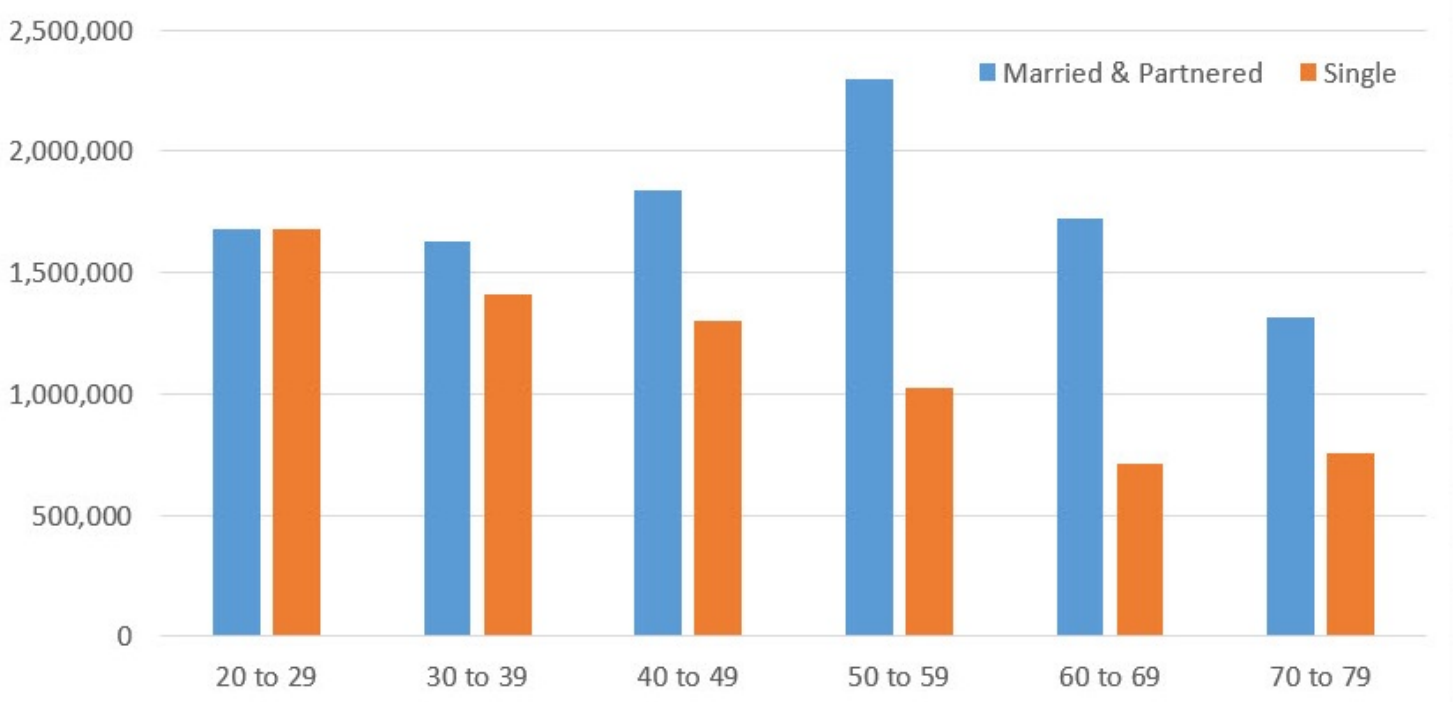

\footnotetext{
${ }^{7}$ As in Auerbach et al.(2016, 2017, 2018), prior to ranking the households, we adjust for household size and economies of shared living by dividing resources for married couples by the square root of two.
} 


\subsection{Computing TCJA-Induced Percentage Changes in Spending of Households in Specific Age and Re- source Percentile Groups}

A household's expected discounted present value of remaining lifetime spending, $\mathrm{S}$, is defined as the difference between resources, $\mathrm{R}$, and the expected discounted present value of remaining lifetime net taxes, $\mathrm{T}$, computed as total taxes paid less transfer payments received. ${ }^{8}$

$$
S=R-T \text {. }
$$

Throughout this analysis, we consider changes in lifetime spending as a result of the TCJA for particular groups (e.g. the rich). To compute group-specific changes in spending under the TCJA, we sum the weighted reduction in taxes for all households in the group and divide by the weighted sum of spending for all within-group households pre-TCJA. ${ }^{9}$ The percent change in the spending for a particular group, $\mathrm{G}$, is

$$
\% \Delta S_{G}=\frac{100 \sum_{i \in G}\left(w_{i} T_{i}^{\text {PreTCJA }}-w_{i} T_{i}^{\text {PostTCJA }}\right)}{\sum_{i \in G} w_{i} S_{i}^{\text {PreTCJA }}}
$$

The weighting scheme in our calculations is described in section 3.5.

\subsection{The Fiscal Analyzer}

As detailed in Kotlikoff (2019), the Fiscal Analyzer (TFA) is a detailed lifecycle consumption-smoothing program that incorporates borrowing constraints. TFA calculates remaining lifetime net taxes and remaining lifetime spending along all survival trajectories and then converts them to present values. TFA includes all federal and state income and sales tax provisions in effect pre- and post- TCJA. It also includes the 2015 changes to Social Security benefit provisions. All federal and some state specific transfer programs are also included. Transfer programs with eligibility and or benefits defined at the county level, including Section 8 Housing Vouchers, Low Income Energy Assistance, and Child Care Assistance are excluded for two reasons. First, detailed information is difficult to find across all jurisdictions. Second, due to rationing not all eligible applicants will obtain these benefits.

The specific list of tax and transfer programs included in our calculations is as follows:

$\underline{\text { Taxes }}$

The Federal Personal Income Tax

The Federal Corporate Income Tax

The FICA Tax

State Income Taxes

State Sales Taxes

State Corporate Income Taxes

\footnotetext{
${ }^{8}$ Spending includes the expected discounted present value of any terminal bequests that arise under a given survival path.

${ }^{9}$ The alternative method is to average, on a weighted basis, each household's remaining lifetime change in spending, but this would be heavily influenced by outliers.
} 
Medicare Part B Premiums

The Federal Estate and Gift Tax

Transfer Programs

Social Security Benefits

Supplemental Security Income

SNAP (state-specific)

Temporary Assistance to Needy Families

Medicaid Benefits (state-specific)

Medicare Benefits

The Affordable Care Act (state-specific)

\subsubsection{TFA's Consumption-Smoothing Dynamic Program}

TFA's lifetime consumption smoothing procedure begins with the reading in of household demographic and economic data. The demographic data include marital status, birth dates of each spouse/partner, maximum ages of life of spouse/partners, birth dates of children, ages at which children will leave the household. The economic data include detailed measures of earnings and assets (for both the past and the future). ${ }^{10}$ TFA assumes inflation and rates of return on regular and retirement account assets, household debts, and current primary home data. ${ }^{11}$ Preferences about the desired degree of consumption smoothing are also included (i.e., the preferred age-living standard path). ${ }^{12}$ The degree and timing of future changes in Social Security benefits, federal taxes, state taxes, and payroll taxes, are also incorporated into the calculations. While TFA is set up to use any data source, including data input directly by an individual, in this study we feed it data on households in the Survey of Consumer Finances (see section 3.4 below).

TFA's default assumption, which can be changed, is that the household seeks to have the same living standard per household member through time. The program obeys the specified desired standard of living profile to the extent possible without violating the household's borrowing constraint. The program simultaneously calculates not just the household's smoothest living standard path, but also its time-varying demands for life insurance (and, thus, the living

\footnotetext{
${ }^{10}$ These include past Social Security covered labor earnings, current labor earnings and projected future labor earnings, regular (non-retirement account) assets, 401(k) and other deductible retirement account assets, Roth retirement assets, current and projected future contributions to each type of retirement account, retirement-account withdrawal choices (start and end date, annuitization and order of withdraws as between Roth and 401(k)-type accounts), Social Security benefit collection choices, defined benefit pensions, information on retirement income from non Social Security-covered employment (this triggers Social Security WEP and GPO provisions).

${ }^{11}$ Rent, mortgage amounts, mortgage lengths, mortgage payments, property taxes, condo fees, homeowners insurance, maintenance, etc. are included, as well as up to two future changes in the primary home, symmetric data on the current vacation home data and up to two changes in the vacation home, other real estate properties.

${ }^{12}$ Other items included are funeral expenses, desired bequests, current life insurance (face and cash values), preferences about maintaining living standards of survivors, contingent plans (e.g., what survivors will earn and how they will change their housing), and the maximum amount the household can borrow.
} 
insurance premiums it will pay each year) and each of the above-referenced taxes and transfer payments. ${ }^{13}$

The problem TFA solves is computationally challenging for three reasons. First, there are tens of thousands of potential paths that could occur. These alternate paths include, for example, various levels of regular and spousespecific retirement account assets in the future when both spouses survive, and also in each future year when one spouse is deceased and the other alive. Take, for example, a 40 year-old couple that could live to 100 . There are over 200,000 survivor contingent regular and retirement account state variables. Second, annual taxes, annual transfer payments, annual discretionary spending, and annual life insurance holdings must be determined simultaneously since taxes and life insurance premiums constrain what can be spent. But what is spent through time determines the path of asset income, which helps determine the path of taxes. Third, the program needs to run in finite time to be useful for research.

TFA's algorithm handles these complexities in a highly efficient manner. Indeed, it solves the typical SCF observation's consumption-smoothing, net taxation, and life insurance needs problem within a half second and does so with precision below $\$ 1$.

\subsection{The Use of The Survey of Consumer Finances}

The Federal Reserve's 2016 Survey of Consumer Finances (SCF) collected highly detailed data from 6254 households. These data included detailed information on household labor and asset income, assets and liabilities, and demographic characteristics. ${ }^{14}$

The SCF combines an area-probability sample of households with a "list" sample of generally wealthier households from administrative tax records from the IRS. The SCF includes sampling weights to account for oversampling of wealthier households from inclusion of the "list" sample and for differential response rates among wealthier groups ${ }^{15}$. The oversampling of wealthy households allows for inference about households in the top 1 percent of the resource distribution. ${ }^{16}$

We run each household in the SCF through TFA to generate the TCJAinduced change in taxes and spending for each household. As in Auerbach et al. (2016, 2018), we restrict our analysis to households with heads between 20 and 79 years old. The SCF does not collect data on respondents' past

\footnotetext{
${ }^{13}$ The precise algorithm is proprietary to Economic Security Planning, Inc., which uses it in its commercial lifetime financial planning tools. But its details are available to academic researchers upon receipt of a request emailed to www.kotilkoff@gmail.com, subject to the signing of a nondisclosure agreement.

${ }^{14}$ Using a multiple imputation algorithm, the Fed includes each household's record in the publicuse SCF dataset in five so-called replicates to account for estimation of non-reported values (item non-response) or for disclosure limitations. We use the first replicate for our analysis. Auerbach et al. $(2016,2018)$ report no significant differences in results across replicates.

${ }^{15}$ Wealthier households have lower response rates, particularly at the highest levels. See Bricker et al. (2016).

${ }^{16}$ For the 2004 SCF, Kennickell (2007) shows that 15.8 percent of sampled households were in the top 1 percent of the net worth distribution for the U.S. with 96.4 percent of these coming from the list sample. Another 38.5 percent of the 2004 SCF-sampled households were in the bottom 50 percent of the net worth distribution with only 5.7 percent of these households coming from the list sample.
} 
earnings histories, which is needed for TFA's Social Security benefit calculation. Consequently, we follow the methodology in Auerbach et al. (2016, 2018) to impute past earnings and forecast future earnings using past waves of the Current Population Survey through 2013. Future mortality of household members, assumed to begin at age 55 and end with certain death at age 100, is also projected using the method described in Auerbach et al. $(2016,2018)$. And, as in that study, the present value of human resources, spending and net taxes are calculated as probability weighted averages of their outcomes for all possible survivor paths for either a single person or married couple. Kotlikoff (2019) provides details of updates to TFA subsequent to the Auerbach et al. (2016, 2018) studies.

\subsection{Generating State-Level Results}

The SCF is a nationwide survey and its household weights permit data aggregations that are representative of the nation, but not of any particular state. While the SCF does collect geographic-specific identifiers, like the state-county FIPS code, they are not available in the public use survey data. Moreover, the sample design of the SCF is not constructed to be representative of states, or other geographies, according to correspondence with administrators of the survey.

In the absence of reliable SCF state-specific data, we perform our stateby-state analysis by running each household in the SCF through TFA for each state and Washington D.C., assuming in each of the 51 runs that all SCF households lived in the same state. That is, we ran all SCF households through TFA under the assumption that they all lived in Alabama, then Alaska, etc..

To form state-specific statistics, we impute a separate weight for each household by doing a statistical match of the SCF data with data from the U.S. Census Bureau's 2016 American Community's Survey (ACS). ${ }^{17}$ In particular, we first restrict both the SCF and ACS to household heads between the ages of 20 and 79. We then partition households into 1536 distinct cells (c) based on the household head's age, race/ethnicity, marital status and educational attainment as well as the value of the primary residence, total household income in 2015 and the presence or absence of at least one child under 17 years of age. For households in a given cell-c, we create the household's weight for each state by multiplying their SCF sample weight by the weighted fraction of cell-c households in the 2016 ACS that reside in that state. Thus, the sum of all state weights for each state will equal the population of that state. We then duplicate all of the data 51 times, running it through TFA to apply all state specific tax and transfer program rules. ${ }^{18}$ We are left with more than 4,500 SCF records in each of the 51-state residencies.

Note that the categorization of rich and poor by resources $\mathrm{R}$ is done at the national level. Thus, examination of the "rich" is not done within the household's assumed state of residence. So for example, California has a higher weighted fraction of households (17.1 percent) in the top 10 percentile than does Mississippi (4.5 percent), and has significantly more residents. Thus, rich households in the U.S. are more likely to be located in California than in Mississippi (18.2 percent of the top 10 percentile of households are in California

\footnotetext{
${ }^{17}$ The ACS includes over 1.3 million households covering 1 percent of the U.S. population.

${ }^{18}$ We remove households with a present value of spending under $\$ 5000$ and households where the program does not converge for every state in the sample.
} 
versus 0.4 percent in Mississippi).

\section{Results}

Here we present evidence that taxpayers living in states that tend to vote Republican in presidential elections (red states) receive a greater benefit on average from the TCJA than taxpayers living in states that tend to vote Democrat (blue states). In particular, we find this state variation is driven by those in top 10 percent of each age cohort's resource distribution. This appears largely due to variation in state and local taxes (SALT) and the TCJA law that affected the ability to deduct these taxes. If we remove the $\$ 10,000$ limitation on SALT that was introduced in the TCJA, the variation by state mostly disappears, particularly for the rich.

It's possible that this state variation is due to differences in age, home values or incomes across state. To test for this, we conduct an experiment where we keep socioeconomic factors across states the same and only allow tax policy to vary. We find our results essentially unchanged by this experiment, suggesting differences across state are mostly due to differences in tax policies between the states.

The first subsection below discusses the variation in the TCJA gains by state and for different points in the resource distribution. In the second subsection, we remove the limitation on the amount of state and local taxes that can be deducted. This adjustment enables us to see how states would have fared if the SALT limitation had not been implemented. In the third subsection, we remove any socioeconomic differences between states and reexamine the results.

\subsection{Variation in the TCJA Gains}

\subsubsection{Variation by state}

According to our calculations, households are projected to pay $\$ 25,000$ less on average, in present value, in net taxes over their lifetimes due to permanent implementation of the TCJA. As indicated in equation (3) and described in Kotlikoff (2019), TFA guarantees that any reduction in expected remaining lifetime net taxes produces an equal-sized increase in expected remaining lifetime spending. Hence, the $\$ 25,000$ decline in average tax payments translates to a $1.5 \%$ increase in spending across all states.

Figure 2 below provides an overview of the TCJA's impacts across the country. The shade of green indicates the magnitude of the state's gain in lifetime spending. The darker the green, the larger the change in lifetime spending of households in the state. States shaded darkest or second darkest green experienced a 1.6 percent to 2.1 percent increase in remaining lifetime spending per household. Households in states shaded very light or light green experienced, on average, a 0.9 to 1.4 percentage increase in remaining lifetime spending.

Figure 3, shows the percentage change in spending resulting from TCJA on the left hand side and the absolute TCJA-induced spending increase on the right hand side, ranked by the percentage change from high to low. The state with the smallest percentage increase in lifetime spending is California - a far leaning blue state - with a gain of 0.9 percent. The state with the 
largest percentage increase is Wyoming- a far leaning red state- with a gain of 2.1 percent. The ten states receiving the smallest percentage spending gain from the tax reform are all blue. Moreover, of the 10 states with the highest average percent TCJA lifetime spending gains, only one, Washington State, is blue. Seven are red and three are purple.

The right side of the figure shows lifetime spending changes in absolute dollar terms. Some states that had a relatively small percentage change averaged relatively larger absolute spending increases. New Jersey is an example. It's spending increase was the ninth lowest in percentage terms (1.3 percent), but it's absolute increase in spending exceeds that of all but two of the red states $(\$ 31,000)$.

Figure 2: Average Percentage Change in Household Lifetime Spending Resulting from TCJA

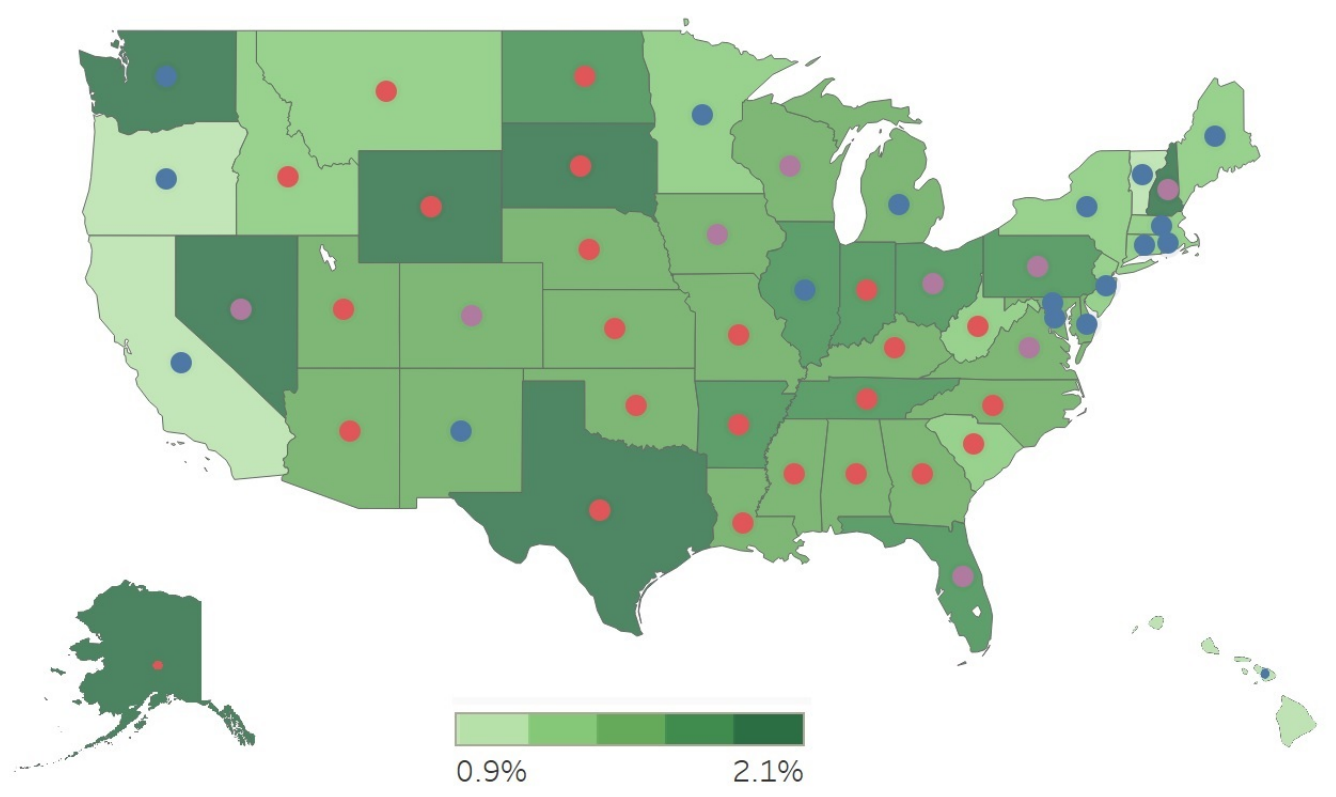

Note: Dots indicate if state is red, blue, or purple. 
Figure 3: Change in Lifetime Spending Resulting From TCJA

Rank ordered by percent change in TCJA gains

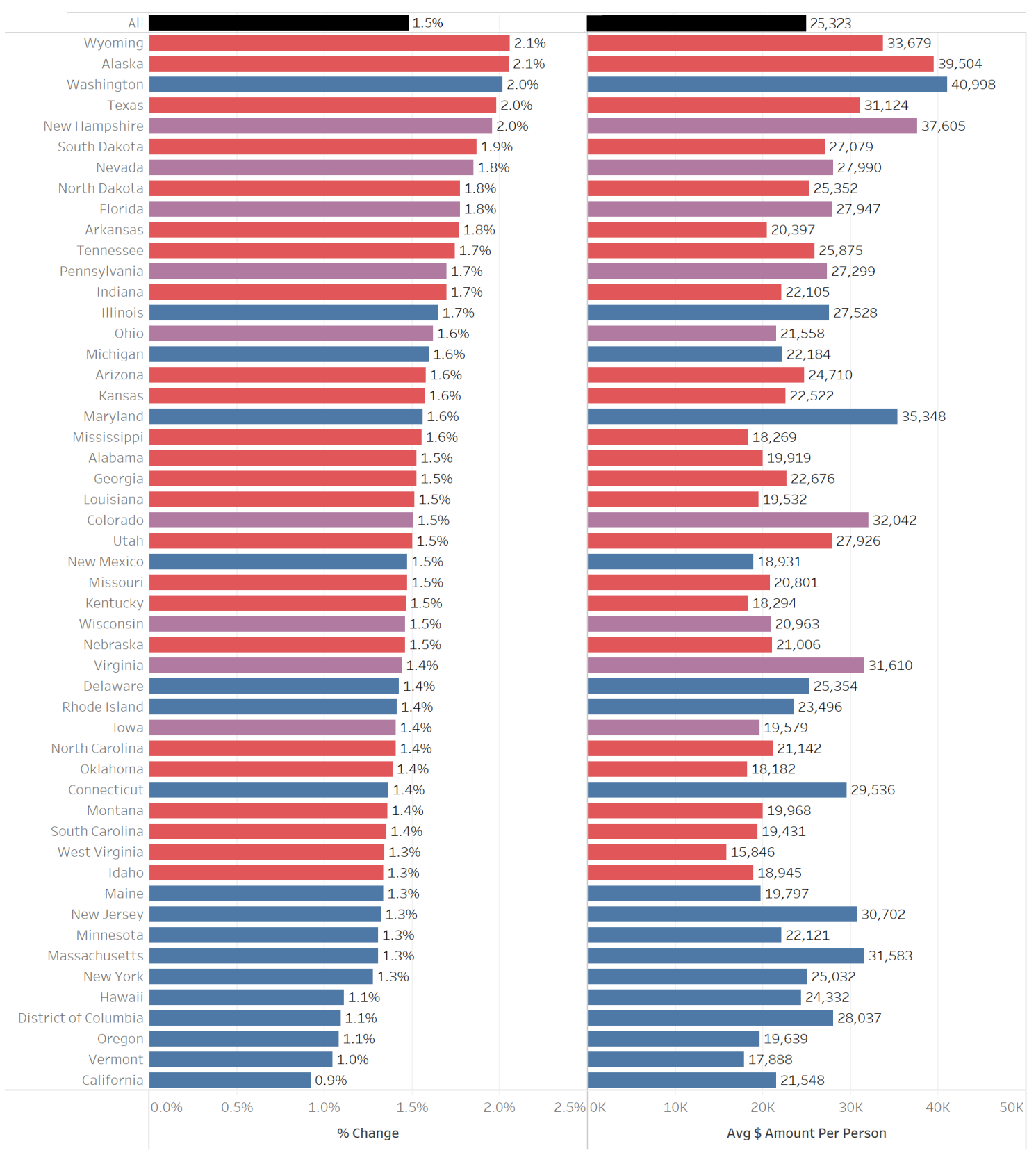

Note: Color of bars indicate if state is red, blue, or purple. We define red states as those that voted Republican in the past five presidential elections by a margin of 5 or more percentage points, on average. Blue states, are those that on average voted Democratic by a margin of 5 or more percentage points in the past five presidential elections. The remaining states are designated as purple states

The left hand side of Figure 3 suggests a systematic relationship between a state's political leanings and the percentage increase in spending due to the change in tax policy. As shown in figure 4, there is in fact a distinct positive relationship between the percentage gain from TJCA and the voting pattern of the state. Figure 4 plots for each state its average percentage change in lifetime 
spending against its average net Republican voter margin over the past five presidential elections. The correlation between the two variables is 0.5 . The weighted regression of each state's percentage spending change from TCJA on a constant and its average Republican voter margin yields a coefficient of 0.009 with a standard error of 0.000002 . In other words, a ten percentage point higher Republican voter margin corresponds to a 0.09 percentage point higher increase in average lifetime spending due to TJCA.

Grouping states together into their Republican or Democratic leanings yields an average of a 1.6 percent gain for red states versus a 1.3 percent gain for blue states. This 30 basis point difference is statistically significant at the 1 percent level. The average lifetime spending gain for purple states is also 1.6 percent and is significantly different from average lifetime spending of blue states at the 1 percent level.

Figure 4: Change in Lifetime Spending Resulting from TCJA

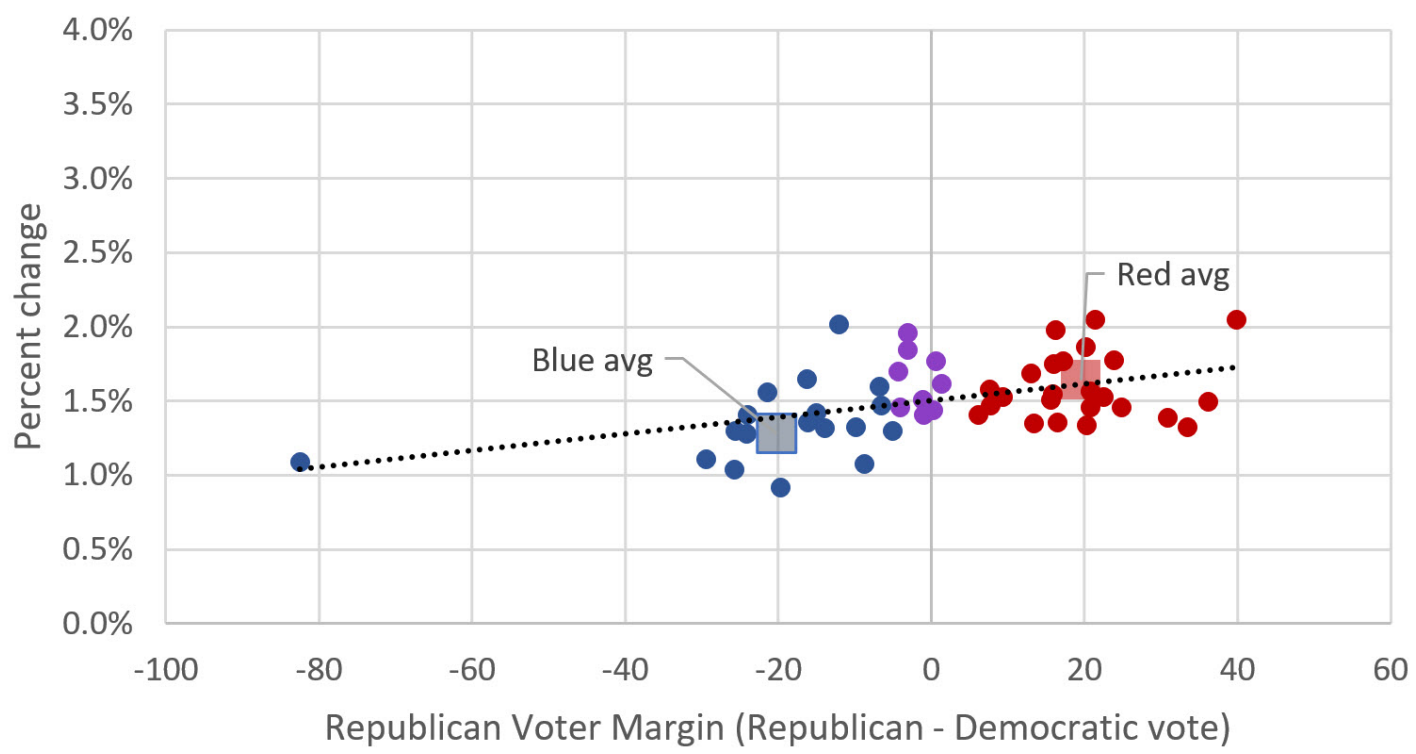

Note: Dots indicate if state is red, blue, or purple.

\subsubsection{State Variation by Resource Level}

State variation in per household average TCJA gains differs by income level. TCJA's biggest impact on the middle- and lower-income households was through its elimination of exemptions, increase in the standard deduction, and, in families with children, increase in the child tax credit. Because the standard deduction changed by such a large amount (from $\$ 6,350$ to $\$ 12,000$ for single filers, from $\$ 12,700$ to $\$ 24,000$ for married filing jointly and widowed tax payers, and from $\$ 9,350$ to $\$ 18,000$ for head of household filers), the Joint Committee on Taxation expects that relatively few people - 18 million (12 percent) down from 46 million (31 percent) - will gain from itemizing their deductions when they file their taxes in 2019. Table 1 shows how the number of people itemizing deductions is expected to change over time by income category. 
Table 1: Estimated Number of Taxpayers Who Itemize Deductions: 2017 vs 2018 (in thousands)

\begin{tabular}{l|r|r|r} 
Income & 2017 & 2018 & Percentage Change \\
\hline Less than $\$ 50,000$ & 5,445 & 1,501 & -72 \\
$\$ 50,000$ to $\$ 100,000$ & 13,305 & 11,091 & -17 \\
$\$ 100,000$ to $\$ 200,000$ & 17959 & 6513 & -64 \\
$\$ 200,000$ to $\$ 500,000$ & 8207 & 4185 & -49 \\
$\$ 500,000$ to $\$ 1,000,000$ & 1089 & 791 & -27 \\
$\$ 1,000,000$ and over & 509 & 444 & -13 \\
Total, All Taxpayers & 46514 & 18012 & -61
\end{tabular}

Source: Joint Committee on Taxation

Note: Income is adjusted gross income plus (1) tax-exempt interest, (2) employer contributions for health plans and life insurance, (3) employer share of FICA tax, (4) workers' compensation, (5) nontaxable Social Security benefits, (6) insurance value of Medicare benefits, (7) alternative minimum tax preference items, (8) individual share of business taxes, and (9) excluded income of U.S. citizens living abroad. Categories are measured at 2018 levels. Table includes non filers, but excludes dependent filers and returns with negative income.

Table 2 shows how the value of the SALT deduction has changed between 2017 and 2018 for different ranges of income. In total, the amount of tax deductions under SALT is expected to fall from $\$ 109$ billion to $\$ 20$ billion, most of which stems from a reduction in the benefits for those with incomes over $\$ 100,000$. In 2017 , nearly all of the total value of SALT deductions $-\$ 99.7$ billion out of $\$ 109$ billion - accrued to those with incomes over $\$ 100,000$. In 2018 taxes, this number is expected to fall to just $\$ 17$ billion, a reduction of $\$ 82$ billion.

Table 2: Estimated Value of the SALT Deduction by Income

\begin{tabular}{llllr}
\hline & \multicolumn{3}{c}{2017} & \multicolumn{2}{c}{2018} \\
\cline { 2 - 5 } Income category & Returns (000s) & Millions $(\$)$ & Returns $(000 \mathrm{~s})$ & Millions $(\$)$ \\
\hline Less than $\$ 50,000$ & 3,303 & 915 & 799 & 224 \\
$\$ 50,000$ to $\$ 100,000$ & 11,988 & 8,796 & 4,097 & 2,580 \\
$\$ 100,000$ to $\$ 200,000$ & 17,650 & 27,878 & 6,382 & 6,920 \\
$\$ 200,000$ to $\$ 500,000$ & 7,816 & 26,160 & 4,148 & 7,081 \\
$\$ 500,000$ to $\$ 1,000,000$ & 1,015 & 11,491 & 780 & 2,191 \\
$\$ 1,000,000$ and over & 490 & 34,202 & 418 & 1,287 \\
Total, All Taxpayers & 42,262 & 109,443 & 16,624 & 20,282 \\
\hline
\end{tabular}

Source: Joint Committee on Taxation

Note: Income is adjusted gross income (AGI) plus: (1) tax-exempt interest, (2) employer contributions for health plans and life insurance,(3) employer share of FICA tax, (4) worker's compensation, (5) nontaxable Social Security benefits, (6) insurance value of Medicare benefits, (7) alternative minimum tax preference items, (8) individual share of business taxes, and (9) excluded income of U S. citizens living abroad. Categories are measured at 2018 levels. 
The amount of SALT a household pays is a function of the household's home value, the nature of property taxation (millage rate, assessment policy, homestead exemptions, etc.), income and the state's income tax rate. The extent to which these factors vary by state will greatly affect the amount of state and local taxes paid, and thus how much can potentially be deducted. State and local tax rates vary substantially by state. As shown in table 3 , blue states tend to face slightly higher taxes (11.5 percent for the median household in blue states versus 10.1 percent in red states). Further, the lowest state and local tax rate is $5.7 \%$ in Alaska (a red state) and the highest state and local tax rate is $14.5 \%$ in Illinois (a blue state). The average home value among blue states is also higher ( $\$ 371$ thousand versus $\$ 209$ thousand). ${ }^{19}$

Table 3: Tax Rates, Home Values, and State and Local Taxes Paid Averaged by Red/Blue/Purple Designation

\begin{tabular}{llll}
\hline & $\begin{array}{l}\text { State and Local } \\
\text { Rates for Median } \\
\text { U.S. Household }\end{array}$ & $\begin{array}{l}\text { Average Home } \\
\text { Value }\end{array}$ & $\begin{array}{l}\text { Amount of State and } \\
\text { Local Taxes for Me- } \\
\text { dian State Household }\end{array}$ \\
\hline Red & $10.2 \%$ & $\$ 208,620$ & $\$ 5,219$ \\
Blue & $11.3 \%$ & $\$ 370,863$ & $\$ 7,950$ \\
Purple & $11 \%$ & $\$ 260,233$ & $\$ 6,371$ \\
All & $10.8 \%$ & $\$ 274,991$ & $\$ 6,386$ \\
\hline
\end{tabular}

Source: Kiernan, John. "2019 Tax Rates by State" and authors' calculations from the American Community Survey

Note: State and local taxes include real estate taxes, vehicle property taxes, income taxes and sales excise taxes. Assumes "Median State Household" has an annual income equal to the mean third quintile income of the state, owns a home at a value equal to the median of the state, owns a car valued at $\$ 24,350$ (the highest-selling car of 2018); and spends annually an amount equal to the spending of a household earning the median state income. Assumes "Median U.S. Household" has an annual income of mean third quintile of U.S. income $(\$ 58,082)$, owns a home valued at median U.S. home value $(\$ 193,500)$, owns a car valued at $\$ 24,350$ (the highest-selling car of 2018), and spends annually an amount equal to the spending of a household earning the median U.S. income.

\footnotetext{
${ }^{19}$ See the Appendix for a full list of average home values and income tax rates by state.
} 
With itemized deductions far less important to middle- and low-income households, one would expect small differences by state in the TCJA's treatment of such households. That's not the case for high-income households. As table 1 indicates, among households with more than $\$ 1$ million in annual income only 13 percent fewer households are expected to itemize deductions in 2018 compared to 2017. In contrast, among households with incomes below $\$ 50,000$, there's a 72 percent predicted decline in itemizers. Since the largest itemizable deduction for high-income households is SALT, the TCJA's limitation of the SALT deduction to $\$ 10,000$ is particularly onerous for higher income households living in high SALT states.

Thus, it's not surprising that when we narrow figure 4 to households who rank among the richest 10 percent in their age cohort by resources, we find even more variation by state in TCJA's average household treatment. Importantly, the relationship between Republican voter margin and percent change in lifetime spending resulting from the TCJA becomes even stronger (see Figure 5). The weighted regression of each state's percentage spending change from the TCJA on a constant and its average Republican voter margin yields a coefficient of 0.02 with a standard error of 0.00001 . In other words, a ten percentage point higher Republican voter margin corresponds to a 0.2 percentage point higher increase in lifetime spending. In contrast, at the opposite side of the income distribution, those in the bottom 10th percentile, experienced similar gains under the TCJA across states (see Figure 6 below).

Figure 5: Percentage Change in Lifetime Spending Resulting from TCJA by Republican Voter Margin, Richest 10 Percent of Households

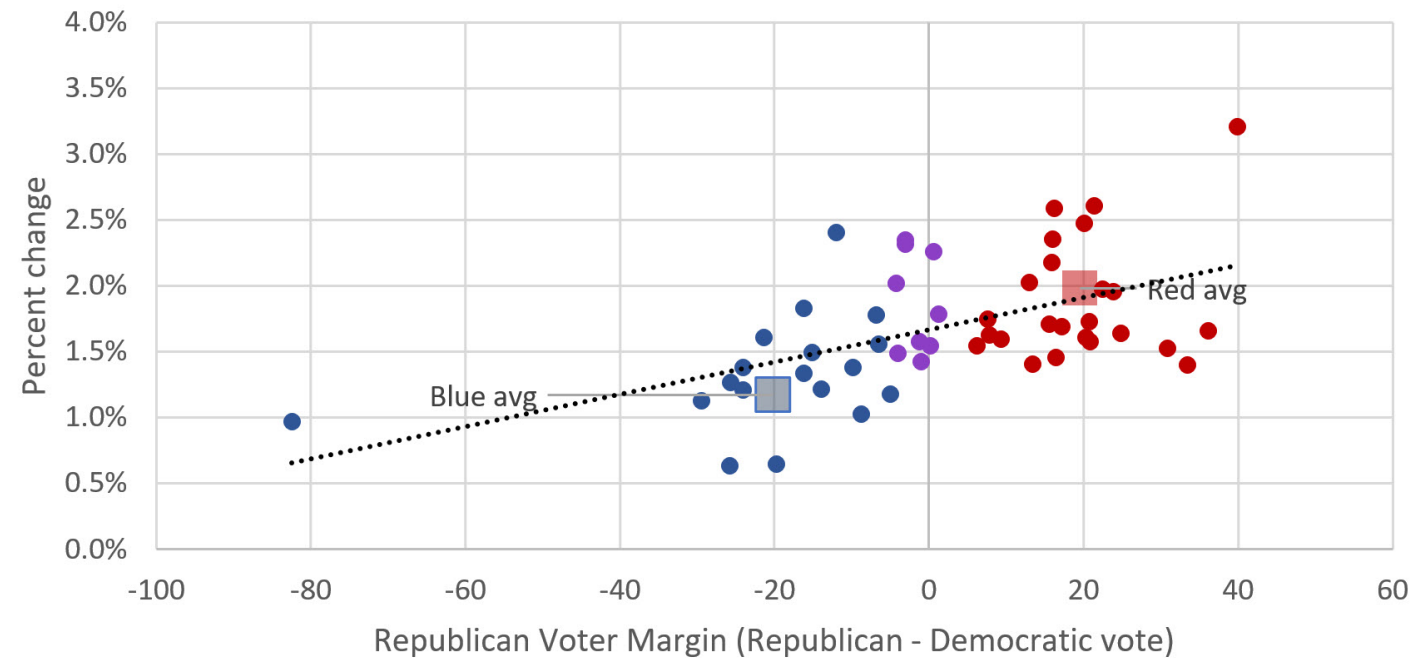

Note: Dots indicate if state is red, blue, or purple. 
Figure 6: Percentage Change in Lifetime Spending Resulting from TCJA by Republican Voter Margin, Poorest 10 Percent of Households

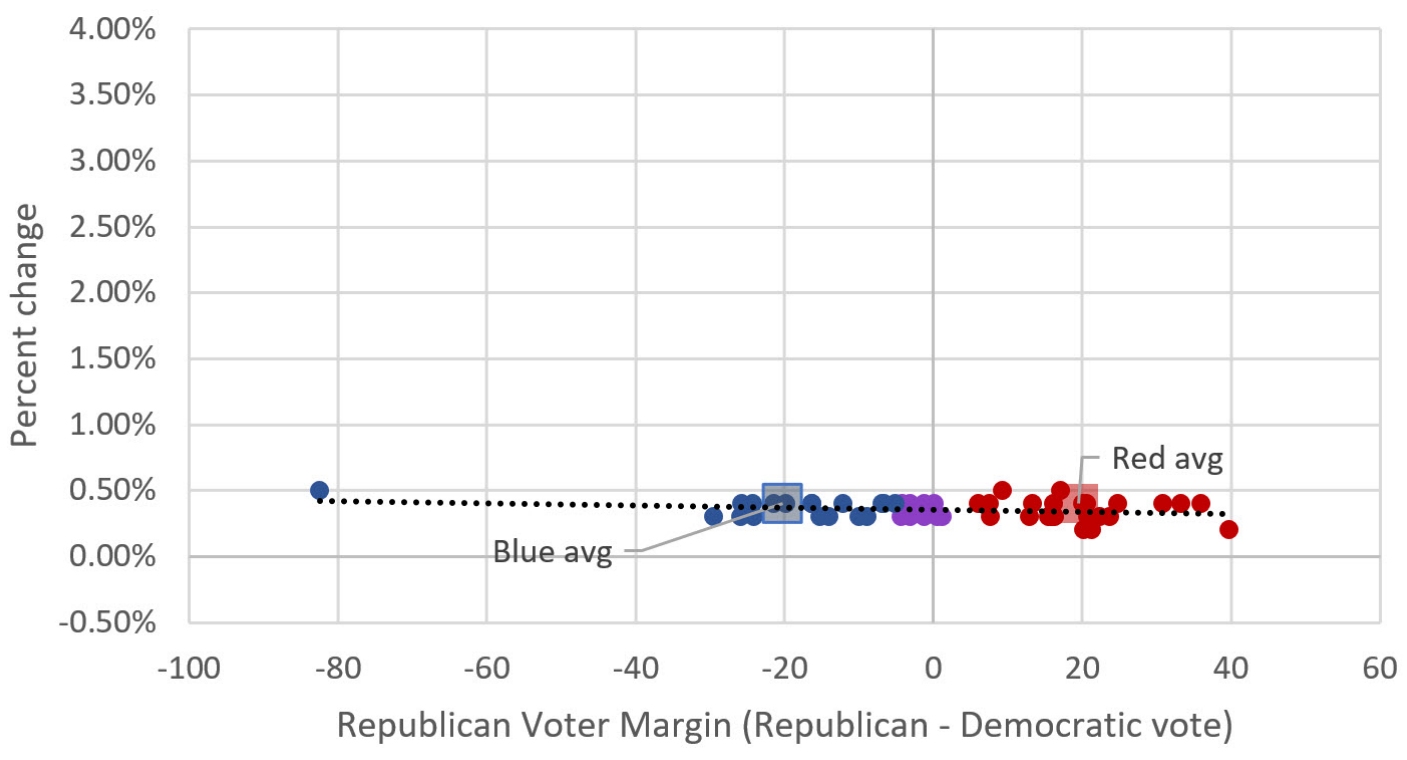

Note: Dots indicate if state is red, blue, or purple.

\subsection{The No-SALT Experiment}

We next repeat our analysis of the TCJA's differential treatment of the rich in red versus blue states, but under the counterfactual assumption that TCJA didn't include a cap on SALT deductions. The left-hand-side of Figure 7 shows average percentage spending changes by state, ranked from high to low, as in Figure 3. The right-hand-side of figure 7 preserves the left-hand-side ordering of states, but displays the spending impact of the TCJA assuming it had been passed with no SALT deduction limitation.

The importance of SALT is apparent. On average, spending would increases by 2.0 percent under the no-SALT scenario versus 1.5 percent under the TCJA. In addition, the red-blue differential is reversed in this scenario: Households in blue states experience a 30 basis point increase in spending relative to those in red states (instead of 30 basis points lower under TCJA).

The ten states with the smallest TCJA spending gains with the SALT limitation experience a notably larger spending increase without the limitation. Instead of experiencing an average spending gain of 1.1 percent under the permanent version of TCJA as legislated, they would have experienced a 2.1 percent gain had the SALT provisions been excluded. This is nearly the same as the average gain of 2.0 percent across all states under the no-SALT scenario.

Figure 8 repeats this experiment for the top 10 percent of households. Importantly, the same result described with respect to the average across states is generally true when we restrict attention to the rich: There is much less variation across states in the TCJA gains under the no-SALT scenario. But the difference between TCJA and no-SALT is larger among those in the top 10 percentile. The average gain under the no-SALT scenario for the top 10th percentile is 2.6 percent, compared to 1.5 percent under the TCJA. There 
is essentially no difference between the TCJA and no-SALT TCJA for the bottom 10 percentile (with both scenarios producing a gain of 0.4 percent).

Figure 7: Change in Lifetime Spending: TCJA versus no-SALT Change Scenario Rank ordered by TCJA gains

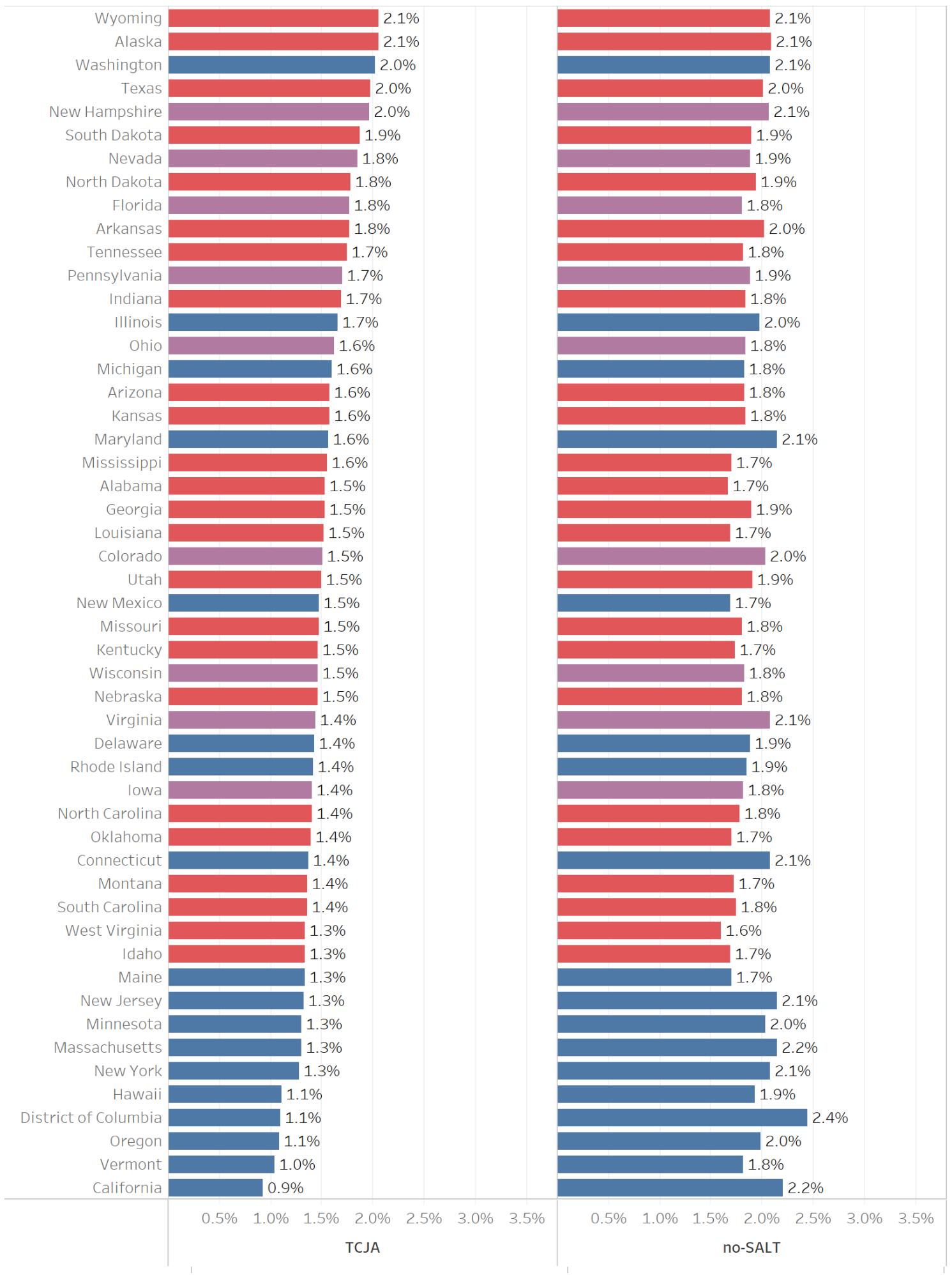

Note: Color of bars indicate if state is red, blue, or purple. 
Figure 8: Change in Lifetime Spending: TCJA versus no-SALT Change Scenario Rank ordered by TCJA gains

Richest 10 Percent of Households

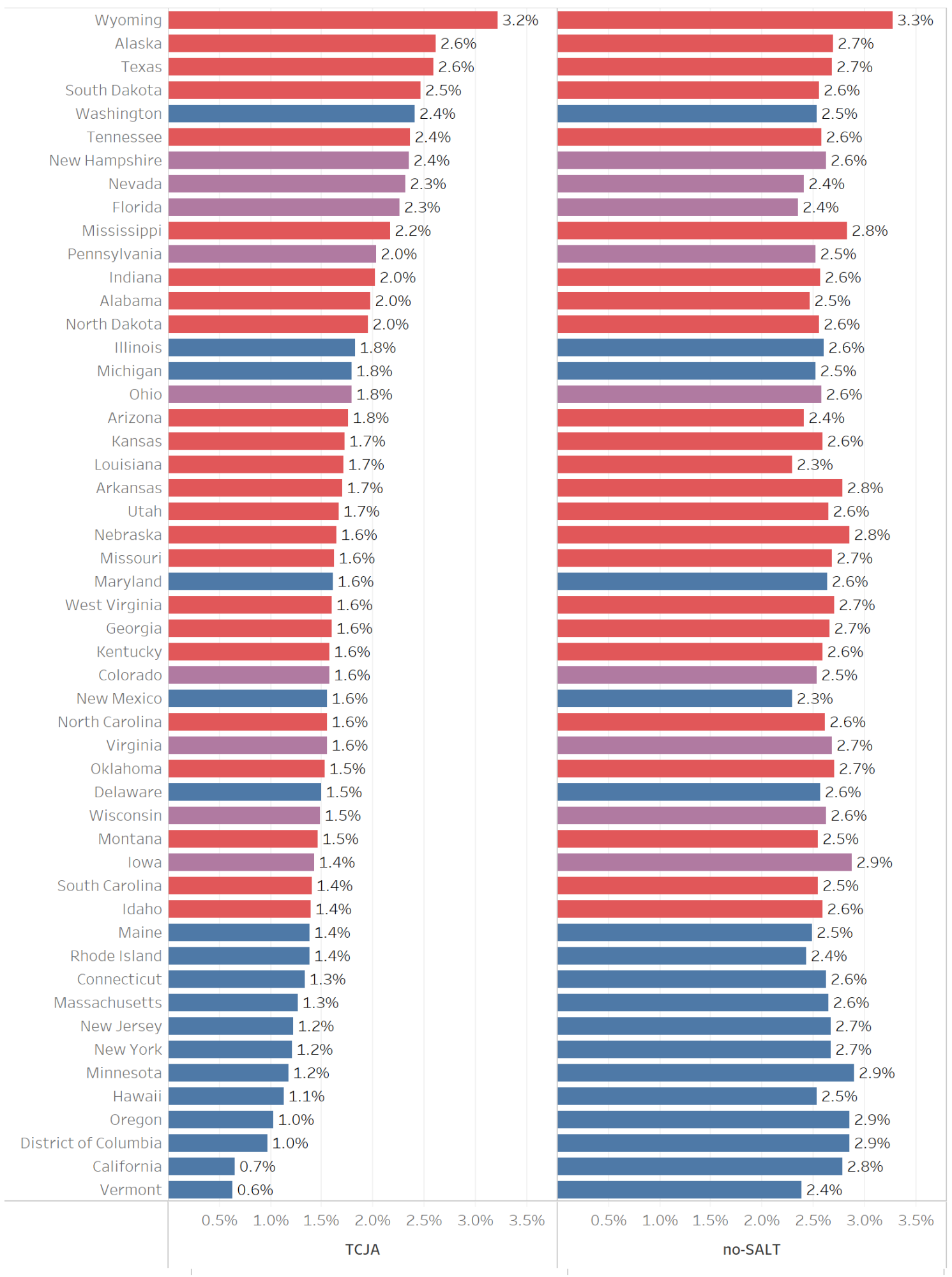

Note: Color of bars indicate if state is red, blue, or purple. 


\subsection{Removing Socioeconomic Factors}

The differential impact of TCJA that we report above is a result of both differences in tax policies across states and differences in demographic characteristics across states. With respect to the effect of demographics, consider for a state which is much younger than an otherwise identical state. Because the older rich are more likely than the younger rich to itemize, TCJA will appear to be benefiting the younger state relative to the older state simply because SALT deduction restrictions will disproportionately impact the latter. In order to isolate the influence of state-level tax policies from state-level demographics, we repeat the experiments cited above using U.S. weights from the SCF, rather than the state-specific weights described in subsection 3.5 above.

The results of these experiments are shown below in Figure 9. The column on the left is the same as the left column of Figure 7 above and shows the change in lifetime spending under the TCJA with the state specific weights applied. The column on the right shows what happens if the U.S. weights are applied to each state instead. If socioeconomic differences between states are driving the state by state variation in the TCJA gains, those differences should be revealed in a comparison of these two columns.

While there are differences for specific states, the average TCJA gain is 1.5 percent with uniform weights as opposed to 1.6 percent with state weights. This suggests that the variation in the TCJA gains by state are mostly a function of differences in tax polices between states.

Importantly, significant differences across states remain even when socioeconomic factors are identical between states. The state with the biggest gain is Nevada (2.0 percent) and the state with the smallest gain is Oregon (1.1 percent). Further, as shown in Figure 10 below, this is also true for the richest 10 percent of households. The average gain in spending under the TCJA for the top 10 percent calculated with state-weights is 1.6 percent versus 1.5 percent when US weights are applied. 
Figure 9: Change in Lifetime Spending Resulting from TCJA State Specific Demographics versus Uniform Demographics Rank ordered by TCJA gains

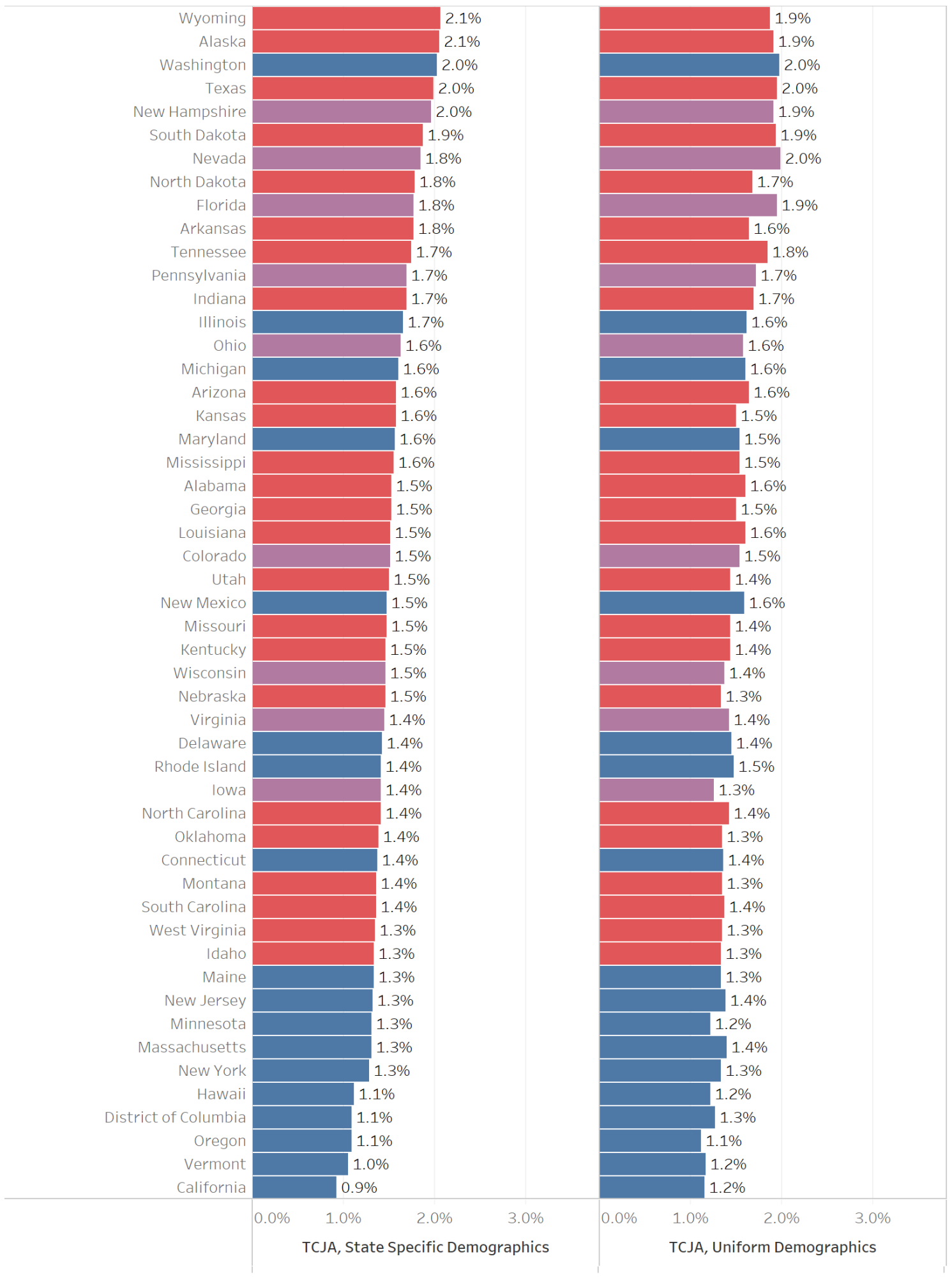

Note: Color bars indicate if state is red, blue, or purple. 
Figure 10: Change in Lifetime Spending Resulting from TCJA

State Specific Demographics versus Uniform Demographics

Rank ordered by TCJA gains

Richest 10 percent of households

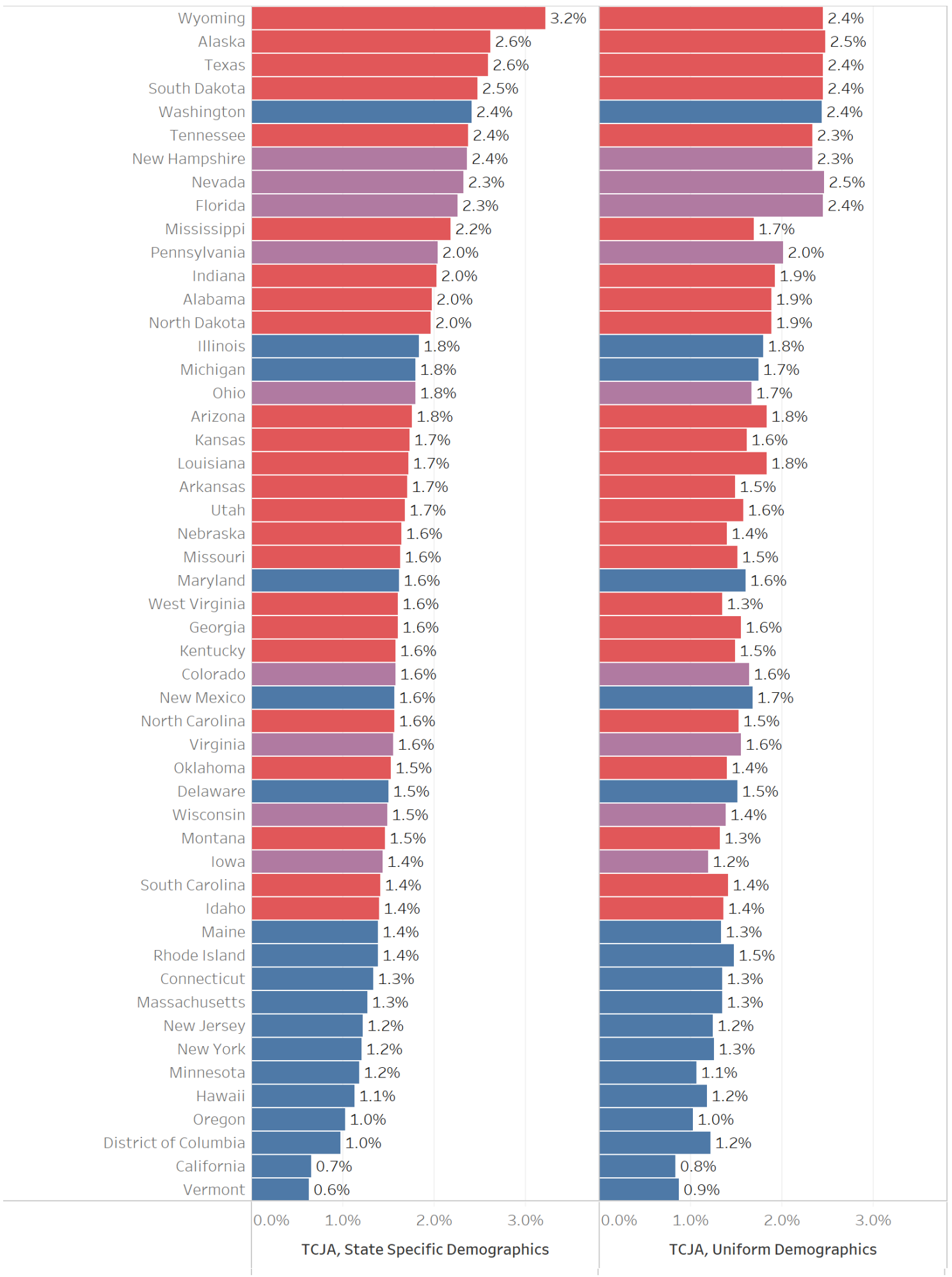

Note: Color of bars indicate if state is red, blue, or purple. 


\section{Summary and Conclusion}

In this paper we estimate the state-by-state effects deriving from permanent implementation of the TCJA. We find a small but important difference in the effects on households across red and blue states. Households in red states enjoyed, on average, a 1.6 percent increase in remaining lifetime spending due to the TCJA compared with 1.3 percent for blue-state households. Among the top 10 percent of households, the differential is larger. Rich households in red states enjoyed a 2.0 percent increase relative to a 1.2 increase among the rich in blue states.

The major factor underlying the TCJA's distinct impact on rich households across red and blue states is the TCJA's $\$ 10,000$ limitation on the deductibility of SALT - state and local taxes. Indeed, as we show, almost all of the difference in the TCJA's treatment of the rich in red and blue states reflects TCJA's SALT deduction limitation. Furthermore, it appears that these differential effects are mainly driven by differences in state tax policies, as opposed to differences in demographics across states (including income and property values).

There are a host of interesting questions that arise from the observations reported in this (and related) work. Do households have incentives to vote for one candidate versus another based on perceived tax advantages offered by the competing political parties? Do voters act on these incentives? As shown by Feldstein and Metcalf (1987), for those that itemize, SALT deductibilty acts as a federal subsidy for state and local tax collections at the rate of their marginal federal tax rate. Gramlich (1985) notes that removal of this subsidy, and the possible consequences in terms of lower state and local government spending, may result in migration of high-income households from high-tax areas to low-tax areas. Will this prediction hold if, as we assume here, the relevant TCJA provisions remain permanent?

Answers to these questions are well beyond the scope of our analysis here. But our results begin to develop a factual basis for potentially addressing these and a variety of other political economy questions.

\section{References}

Auerbach, Alan J., Laurence J. Kotlikoff, and Darryl Koehler. 2016. "U.S. Inequality, Fiscal Progressivity, and Work Disincentives." NBER working paper no. 22032 .

Auerbach, Alan J., Laurence J. Kotlikoff, and Darryl Koehler. 2018. "The New Tax Bill - Winners and Losers." Manuscript available at https://www.kotlikoff.net/node/633

Auerbach, Alan J., Laurence J. Kotlikoff, Darryl Koehler and Manni Yu. 2017. "Is Uncle Sam Inducing the Elderly to Retire?" in Tax Policy and the Economy. NBER vol. 31, no 1, pp. 1-42.

Benzell, Seth G., Laurence J. Kotlikoff, Guillermo Lagarda. 2017a. "Simulating Business Cash Flow Taxation: An Illustration Based on the "Better Way" U.S. Corporate Tax Reform." NBER working paper 23675. 
Benzell, Seth G., Laurence J. Kotlikoff, Guillermo Lagarda. 2017b. "Simulating the Unified Framework Tax Reform." October.

https://www.kotlikoff.net/sites/default/files/

Simulating the Unified Framework Tax Reform Plan_0.pdf

Bricker, Jesse, Alice Henriques, Jacob Krimmel, and John Sabelhaus. 2016. "Measuring Income and Wealth at the Top Using Administrative and Survey Data." Brookings Papers on Economic Activity, Spring 2016, pp. 261-312.

Feldstein, Martin and Gilbert Metcalf. 1987. "The Effect of Federal Tax Deductibility on State and Local Taxes and Spending." Journal of Political Economy 95(4): 710-736.

Gale, William, Hilary Gelfond, Aaron Krupkin, Mark J. Mazur, and Eric Toder. 2018. "Effects of the Tax Cuts and Jobs Act: A Preliminary Analysis." Urban-Brookings Tax Policy Center Research Report.

Gramlich, Edward M. 1985. "The Deductibility of State and Local Taxes." National Tax Journal Vol. 38, No. 4 (December, 1985), pp. 447-465.

Lindsey, Lawrence B. 1988. "Federal Deductibility of State and Local Taxes: A Test of Public Choice by Representative Government." Chapter 5 in NBER book Fiscal Federalism: Quantitative Studies (1988), Harvey S. Rosen, editor (p. 137 - 176).

Kennickel, Arthur. 2007. "The Role of Over-sampling of the Wealthy in the Survey of Consumer Finances."

https://www.federalreserve.gov/econresdata/scf/files/isi2007.pdf

Kiernan, John. 2019. "2019 Tax Rates by State."

https://wallethub.com/edu/best-worst-states-to-be-a-taxpayer/2416/

Kotlikoff, Laurence J. 2019. "The Fiscal Analyzer Online Documentation." Manuscript available at https://www.kotlikoff.net/node/672

Nunns, Jim, Len Burman, Ben Page, Jeff Rohaly, and Joe Rosenberg. 2016. "An Analysis of Donald Trump's Revised Tax Plan." Urban-Brookings Tax Policy Center Research Report.

Ryan, Paul. 2016. "A Better Way: Tax."

https://www.novoco.com/sites/default/files/atoms/files/

ryan_a_better_way_policy_paper_062416.pdf

Sammartino, Frank, and Kim Rueben. 2016. "Revisiting the State and Local Tax Deduction." Urban-Brookings Tax Policy Center Research Report.

Sammartino, Frank, Philip Stallworth and David Weiner. 2018. "The Effect of the TCJA Individual Income Tax Provisions Across Income Groups and Across the States." Urban-Brookings Tax Policy Center Research Report. 
Staff of the Joint Committee on Taxation. 2018. "Tables Related to the Federal Tax System as in Effect 2017 through 2026." Joint Committee on Taxation.

\section{Appendix}

Table 4: Tax Rates, Home Values, and State and Local Taxes Paid

\begin{tabular}{llll}
\hline & $\begin{array}{l}\text { State and Local } \\
\text { Rates for Median } \\
\text { U.S. Household }\end{array}$ & $\begin{array}{l}\text { Average Home } \\
\text { Value }\end{array}$ & $\begin{array}{l}\text { Amount of State and } \\
\text { Local Taxes for Me- } \\
\text { dian State Household }\end{array}$ \\
\hline Alaska & $5.7 \%$ & $\$ 286189$ & $\$ 4439$ \\
Delaware & $6.1 \%$ & $\$ 271288$ & $\$ 4047$ \\
Montana & $7.1 \%$ & $\$ 269771$ & $\$ 3968$ \\
Wyoming & $8.1 \%$ & $\$ 278089$ & $\$ 4902$ \\
Nevada & $8.2 \%$ & $\$ 283458$ & $\$ 4797$ \\
Utah & $8.4 \%$ & $\$ 293591$ & $\$ 5638$ \\
Florida & $8.4 \%$ & $\$ 270802$ & $\$ 4396$ \\
Idaho & $8.6 \%$ & $\$ 226958$ & $\$ 4431$ \\
Colorado & $8.7 \%$ & $\$ 374343$ & $\$ 6009$ \\
Tennessee & $8.7 \%$ & $\$ 204838$ & $\$ 4183$ \\
District of Columbia & $8.9 \%$ & $\$ 625321$ & $\$ 8487$ \\
California & $8.9 \%$ & $\$ 211428$ & $\$ 4703$ \\
South Carolina & $9 \%$ & $\$ 332659$ & $\$ 5948$ \\
Oregon & $9.1 \%$ & $\$ 175313$ & $\$ 4186$ \\
Alabama & $9.1 \%$ & $\$ 157126$ & $\$ 4167$ \\
West Virginia & $9.7 \%$ & $\$ 259099$ & $\$ 5350$ \\
Arizona & $9.7 \%$ & $\$ 286830$ & $\$ 7152$ \\
New Hampshire & $9.9 \%$ & $\$ 208900$ & $\$ 5850$ \\
North Dakota & $10 \%$ & $\$ 214359$ & $\$ 4931$ \\
New Mexico & $10.4 \%$ & $\$ 222388$ & $\$ 5403$ \\
Georgia & $10.4 \%$ & $\$ 193820$ & $\$ 4922$ \\
Louisiana & $10.5 \%$ & $\$ 685545$ & $\$ 5826$ \\
Hawaii & $10.6 \%$ & $\$ 3376827$ & $\$ 7409$ \\
North Carolina & $10.6 \%$ & & \\
Virginia & $10.7 \%$ & &
\end{tabular}

Source: Kiernan, John. "2019 Tax Rates by State" and Author's calculations from the American Community Survey

Note: State and local taxes include real estate taxes, vehicle property taxes, income taxes and sales excise taxes. Assumes "Median State Household" has an annual income equal to the mean third quintile income of the state, owns a home at a value equal to the median of the state, owns a car valued at $\$ 24,350$ (the highest-selling car of 2018); and spends annually an amount equal to the spending of a household earning the median state income. Assumes "Median U.S. Household" has an annual income of mean third quintile of U.S. income $(\$ 58,082)$, owns a home valued at median U.S. home value $(\$ 193,500)$, owns a car valued at $\$ 24,350$ (the highest-selling car of 2018); and spends annually an amount equal to the spending of a household earning the median U.S. income. 
Table 5: Tax Rates, Home Values, and State and Local Taxes Paid, Continued

\begin{tabular}{|c|c|c|c|}
\hline & $\begin{array}{l}\text { State and Local } \\
\text { Rates for Median } \\
\text { U.S. Household }\end{array}$ & $\begin{array}{l}\text { Average Home } \\
\text { Value }\end{array}$ & $\begin{array}{l}\text { Amount of State and } \\
\text { Local Taxes for Me- } \\
\text { dian State Household }\end{array}$ \\
\hline Massachusetts & $10.8 \%$ & $\$ 444081$ & $\$ 9175$ \\
\hline South Dakota & $11 \%$ & $\$ 197356$ & $\$ 5626$ \\
\hline Vermont & $11.2 \%$ & $\$ 259807$ & $\$ 6992$ \\
\hline Arkansas & $11.3 \%$ & $\$ 162859$ & $\$ 4850$ \\
\hline Minnesota & $11.3 \%$ & $\$ 249862$ & $\$ 7185$ \\
\hline Missouri & $11.3 \%$ & $\$ 195100$ & $\$ 5653$ \\
\hline Oklahoma & $11.4 \%$ & $\$ 169411$ & $\$ 5297$ \\
\hline Maryland & $11.4 \%$ & $\$ 368012$ & $\$ 9392$ \\
\hline Maine & $11.7 \%$ & $\$ 222236$ & $\$ 6323$ \\
\hline Indiana & $11.8 \%$ & $\$ 167347$ & $\$ 5814$ \\
\hline Mississippi & $12 \%$ & $\$ 152118$ & $\$ 5056$ \\
\hline Washington & $12.1 \%$ & $\$ 381518$ & $\$ 8716$ \\
\hline Kentucky & $12.3 \%$ & $\$ 172111$ & $\$ 5609$ \\
\hline New Jersey & $12.4 \%$ & $\$ 395402$ & $\$ 11119$ \\
\hline Michigan & $12.4 \%$ & $\$ 182871$ & $\$ 5951$ \\
\hline Texas & $12.7 \%$ & $\$ 220989$ & $\$ 6576$ \\
\hline Iowa & $12.9 \%$ & $\$ 179461$ & $\$ 6546$ \\
\hline Ohio & $13.1 \%$ & $\$ 176557$ & $\$ 6247$ \\
\hline Rhode Island & $13.2 \%$ & $\$ 303227$ & $\$ 8667$ \\
\hline Wisconsin & $13.3 \%$ & $\$ 211559$ & $\$ 7199$ \\
\hline Kansas & $13.4 \%$ & $\$ 185462$ & $\$ 6813$ \\
\hline Nebraska & $13.4 \%$ & $\$ 179799$ & $\$ 6778$ \\
\hline New York & $13.7 \%$ & $\$ 435167$ & $\$ 10074$ \\
\hline Pennsylvania & $13.8 \%$ & $\$ 222075$ & $\$ 7580$ \\
\hline Connecticut & $14.4 \%$ & $\$ 377209$ & $\$ 10987$ \\
\hline Illinois & $14.9 \%$ & $\$ 247626$ & $\$ 8585$ \\
\hline
\end{tabular}

Source: Kiernan, John. "2019 Tax Rates by State" and Author's calculations from the American Community Survey

Note: State and local taxes include real estate taxes, vehicle property taxes, income taxes and sales excise taxes. Assumes "Median State Household" has an annual income equal to the mean third quintile income of the state, owns a home at a value equal to the median of the state, owns a car valued at $\$ 24,350$ (the highest-selling car of 2018); and spends annually an amount equal to the spending of a household earning the median state income. Assumes "Median U.S. Household" has an annual income of mean third quintile of U.S. income $(\$ 58,082)$, owns a home valued at median U.S. home value $(\$ 193,500)$, owns a car valued at $\$ 24,350$ (the highest-selling car of 2018); and spends annually an amount equal to the spending of a household earning the median U.S. income. 